\title{
Method Development, Validation, Monitoring, Seasonal Effect and Risk Assessment of Multiclass Multi Pesticide Residues in Surface and Ground Water of New Alluvial Zone in Eastern India
}

Sudip Bhattacharyya

Bidhan Chandra Krishi Viswavidyalaya

Rajlakshmi Poi

Bidhan Chandra Krishi Viswavidyalaya

Swagata Mandal

Bidhan Chandra Krishi Viswavidyalaya

Moni Baskey(Sen)

The University of Burdwan

Dipak Kumar Hazra

Bidhan Chandra Krishi Viswavidyalaya

Supradip Saha

Indian Agricultural Research Institute

Rajib Karmakar ( $\square$ rajibc183@rediffmail.com )

Bidhan Chandra Krishi Viswavidyalaya https://orcid.org/0000-0002-0345-5647

Research Article

Keywords: LLE, RQ, GC-MS, Seasonal effect, monitoring, Risk assessment, Environmental water

Posted Date: July 13th, 2021

DOI: https://doi.org/10.21203/rs.3.rs-620759/v1

License: (c) (i) This work is licensed under a Creative Commons Attribution 4.0 International License. Read Full License

Version of Record: A version of this preprint was published at Environmental Science and Pollution Research on October 18th, 2021. See the published version at https://doi.org/10.1007/s11356-021-16959-9. 


\section{Abstract}

A liquid-liquid extraction (LLE) method consisting gas chromatography-mass spectrometric (GC-MS) determination of thirty six pesticides in environmental waters was standardized. The method was validated as per SANTE/11813/2017 guidelines. Effect of three seasons namely summer, monsoon and winter on monitoring of pesticide residues in environmental waters (river, pond and tube well) of rural area was studied and subsequently risk assessment was evaluated. Within two districts (Nadia and North 24paraganas) of new alluvial zone in eastern India, six different places were chosen for sampling of river water. On the contrary, six different ponds and tubewells as well were considered for sampling. 144 samples of 2 liter each (48 each of river, pond and tubewell water) of each district irrespective of seasons were analyzed during the study period. Each water sample $(750 \mathrm{ml})$ was extracted with ethylacetate:dichloromethane (8:2). The total residue was reconstituted in acetone $(1 \mathrm{ml})$ and analysed in GC-MS after proper filtration with $0.22 \mu \mathrm{m}$ nylon syringe filter. Average percent recovery ranged from 77.84 to 118.15 . Irrespective of seasons, maximum total organochlorine (OC) and organophosphorous (OP) pesticide residues were dominated respectively in river and pond water. Irrespective of types of environmental waters, monsoon (July to October) showed presence of total maximum pesticide residues. Risk Quotient (RQ) [acute and chronic] was calculated respectively in pond and river water. Only Seven water samples of tubewell were contaminated with butachlor and chlorpyriphos, although in nonsignificant average amount $\left(<0.1 \mathrm{ngml}^{-1}\right)$, irrespective of seasons and thus safe for consumption.

\section{Introduction:}

West Bengal is the fourth largest populated state in India. The population density is $1100 / \mathrm{km}^{2}$ in 2020 . Barrackpore and Kalyani are two important sub-division towns of west Bengal having population densities $11,500 / \mathrm{km}^{2}$ and 7,500/ $\mathrm{km}^{2}$ respectively. The present study was aimed to carry out at Barrackpore and Kalyani because these two locations are situated in new alluvial zone of the river Hooghly (Ganga) and are developed agriculturally as well as industrially. Three important sources of environmental waters (river, pond and tubewell) serve as domestic, agricultural and industrial consumption. The water of Hooghly River specially is used by the respective municipalities as drinking water after treatment in various plants. Besides, the same water is used in agriculture through irrigation and consumed by various industries directly (KMDA 2017). Water is very crucial for sustaining life. About $50 \%$ of urban people and $80 \%$ of water for rural people in India are affected by water pollution and therefore scarcity of pure drinking water is being created (Hegde 2012). Environmental waters are usually contaminated with point and non-point source of contamination. However, a major source of water contamination comes from nonpoint sources (Calhoun 2005). Enormous researchers (Ongley et al. 1992; Rickert, 1993; Kaushik et al. 2008, 2012; Maurya and Kumar 2013; Toccalino et al. 2014; Székács et al. 2015; Mohamed and Ahmed 2020) reported contamination of environmental waters. But literature of research in these two areas under present study is scarce. Due to dense population, sources of environmental waters including river, pond and tubewell are limiting for use and consumption. Therefore, the chances of contamination are more. In India, during 2014-15 to $2019-20$ consumption of chemical pesticides in agriculture has been increased by $7 \%$ in comparison to bio-pesticides by $34 \%$.

Awareness is therefore growing towards quality assurance and bio-safety in agriculture. At this point, only persistent pesticides may cause contamination and/or pollution of environmental waters. Considering the fact, thirty six pesticides (12 organochlorines, 7 organophosphates, 7 synthetic pyrethroids and 10 others) were chosen based on the screening of literature and farmers' use in these localities.

Movement of pesticides creates three problems when these reach from the application sites to non-target regions. The possible effects are environmental contamination, economic loss and inefficient pest control (Duttweiler and Malakhov 1977; Waite et al. 2002). The transportation of pesticides and its degradation products to surface waters from soil depends on several factors, including environmental weather condition, soil characteristics, topography, agricultural practices and chemical properties of individual pesticides (Leonard et al. 1988; Arias-Estévez, et al. 2008). As there are huge variations in temperature, rainfall and humidity in seasons like summer, monsoon and winter in these locations (Fig. 1) seasonal effects are also considered for investigation under the present study. Though previous study of overall environmental effect on surface water is available (Mondal et al., 2018) but the data of rainy season correlated with non-point source contamination is pending. So, there is a requirement of the correlation between seasonal residue data and non-point source of contamination. Various methods like solid phase extraction (SPE) (Tsochatzis et al. 2012; Sangchan et al. 2012; Kouzayhaet al. 2012; Maurya and Kumar 2013) and liquid-liquid extraction (LLE) (Singh and Mishra 2009; Kaushik et al. 2012; Erkmen et al. 2013) are available to analyse pesticide residues in water. To analyse pesticide residues in water samples Solid Phase Extraction (SPE) is usually applied as it is an easy and fast process (Hatrík and Tekel 1996). The Liquid Liquid Extraction (LLE) method is more reliable than SPE method (Tan 1992). Commercial SPE cartridges or disks have been shown to give extraneous peaks attributed to phthalate esters contained in the housing materials of the cartridges, especially when GC-ECD is used for analysis (Awofolu and Fatoki 2003). In this present method involving LLE three different solvent mixtures namely $S_{1}$ (EA:DCM 8:2), $S_{2}$ (Hexane:DCM 8:2) and $S_{3}(100 \%$ DCM) were considered to check efficiency of extraction of pesticide residues from water samples. Monitoring of 36 pesticide residues was done collecting samples 
from Hooghly River, ponds and tubewells maintaining the sampling protocol. Focusing on the ecological risk of pesticides of non-point source, close proximities and huge connectivities with surrounding areas and limited dilution potentials were observed (Karaouzas et al. 2011; Schulz 2004). Therefore, ecological risk assessment is very important evaluating process of toxic effects of pesticide on non-target organism in aquatic system. Based on the result found in the monitoring study, risk assessment was investigated.

\section{Materials And Methods: Study area:}

Barrackpore $\left(22^{\circ} 76^{\prime} \mathrm{N}\right.$ and $\left.88^{\circ} 37^{\prime} \mathrm{E}\right)$ and Kalyani $\left(22^{\circ} 58^{\prime} \mathrm{N}\right.$ and $\left.88^{\circ} 26^{\prime} \mathrm{E}\right)$, two sub-divisional metropolitan towns of respective districts of North 24Parganas and Nadia have major industrial and agricultural area. Nadia has 79.48\% of agricultural area (Matirkatha 2016) whereas Barrackpore is one of the dense industrial areas of West Bengal. Both are situated at the bank of Hooghly River (Ganga River), the water of which is the source of water treatment plants for drinking, agriculture, industrial use and aquaculture (KMDA 2017). Diversified cropping pattern is found in these two areas throughout the year.

\section{Sampling:}

River water (RW), pond water (PW) and tubewell water (TW) samples were collected for consecutive 48 weeks to monitor the pesticide residues in the aquatic systems of study area. A total of 144 samples (48 each of river, pond and tube-well water) from each district were collected throughout the year covering winter (November to February), summer (March to June) and monsoon (July to October) seasons. Six different sampling points in river, six different ponds and six different tube-wells were chosen for sampling purposes (Fig. 2). Ponds and tube-wells chosen for sample collection are located within 2-3 km radius under domestic, agricultural and industrial activities. Amber glass bottles (2 liter) with stopper cap were washed with commercial detergent using hot water and rinsed with deionized water and acetone. Bottles were then dried in an oven at $100^{\circ} \mathrm{C}$ and stored until use for sampling. Samples were collected from a depth of $1 \mathrm{ft}$ from the surface of river and pond water using Kemmerer water sampler and kept in ice box at $4^{0} \mathrm{C}$. A $2.0 \%$ solution of Sodium azide $\left(\mathrm{NaN}_{3}\right)$ was used for the protection of water samples from microbial growth. Samples were extracted immediately and processed subsequently.

\section{Chemicals and Reagents:}

A total of 36 pesticides covering different groups namely insecticides, herbicides, fungicides and acaricides were selected for the present study (Table 1). All certified reference materials (CRMs) were purchased from Dr. Ehrenstorfer GmbH, Augsburg, Germany with purity mostly of $>97 \%$. LC-MS grade dichloromethane (DCM), hexane, acetone and ethylacetate (EA) were obtained from J.T. Baker, Avantor, USA. Analytical grade anhydrous magnesium sulphate, sodium chloride and sodium sulphate were obtained from Rankem, India. Anhydrous magnesium sulphate was heated at $450^{\circ} \mathrm{C}$ for 5 hours to remove phthalets and then cooled naturally and stored in a desiccator. 
Table 1

Parameters recovery experiments of selected pesticides in GC-MS.

\begin{tabular}{|c|c|c|c|c|c|c|c|c|c|c|c|}
\hline \multirow{2}{*}{$\begin{array}{l}\text { Sl. } \\
\text { No. }\end{array}$} & \multirow[t]{2}{*}{ Pesticides } & \multirow{2}{*}{$\mathrm{RT}^{\mathrm{a}}$} & \multicolumn{3}{|c|}{$\mathrm{m} / \mathrm{z}$ for confirmation with ion ratio } & \multirow[t]{2}{*}{${ }^{b} R^{2}$} & \multirow{2}{*}{$\begin{array}{l}\mathrm{LOQ}^{\mathrm{c}} \\
(\mathrm{ng} / \mathrm{ml})\end{array}$} & \multicolumn{3}{|c|}{ Recovery } & \multirow[t]{2}{*}{ RPD $^{e}$} \\
\hline & & & $\begin{array}{l}\text { Target } \\
\text { lon }\end{array}$ & $\begin{array}{l}\mathrm{Q}_{1} \\
\left(\% \mathrm{Q}_{1} / \mathrm{T}\right)\end{array}$ & $\begin{array}{l}\mathrm{Q}_{2} \\
\left(\% \mathrm{Q}_{2} / \mathrm{T}\right)\end{array}$ & & & $\begin{array}{l}\mathrm{LOQ} \\
\left(S D^{d}\right)\end{array}$ & $\begin{array}{l}2 x \\
\text { LOQ }\end{array}$ & $5 x L O Q$ & \\
\hline 1 & $\begin{array}{l}\text { 4-Br 2-Cl- } \\
\text { phenol }\end{array}$ & 9.01 & 208 & $\begin{array}{l}172 \\
(42.09 \%)\end{array}$ & $\begin{array}{l}170 \\
(32.58 \%)\end{array}$ & 0.996 & 0.044 & $\begin{array}{l}110.52 \\
(5.23)\end{array}$ & 91.3 & 92.9 & 4.16 \\
\hline 2 & Trifluralin & 13.69 & 306 & $43(44.72 \%)$ & $\begin{array}{l}264 \\
(40.28 \%)\end{array}$ & 0.998 & 0.041 & $\begin{array}{l}97.44 \\
(6.33)\end{array}$ & 85.6 & 101.43 & 4.92 \\
\hline 3 & Phorate & 14.39 & 75 & $\begin{array}{l}121 \\
(50.28 \%)\end{array}$ & $\begin{array}{l}260 \\
(43.29 \%)\end{array}$ & 0.997 & 0.02 & $\begin{array}{l}99.31 \\
(9.37)\end{array}$ & 101.56 & 106.23 & 6.83 \\
\hline 4 & $\mathrm{a}-\mathrm{HCH}$ & 14.67 & 181 & $\begin{array}{l}183 \\
(93.37 \%)\end{array}$ & $\begin{array}{l}219 \\
(51.04 \%)\end{array}$ & 0.999 & 0.007 & $\begin{array}{l}113.82 \\
(2.7)\end{array}$ & 90.69 & 82.92 & 12.14 \\
\hline 5 & Atrazine & 15.38 & 200 & $\begin{array}{l}215 \\
(97.23 \%)\end{array}$ & $58(76.68 \%)$ & 0.998 & 0.048 & $\begin{array}{l}107.43 \\
(10.20)\end{array}$ & 100.64 & 99.54 & 15.09 \\
\hline 6 & $\beta-\mathrm{HCH}$ & 15.6 & 181 & $\begin{array}{l}183 \\
(68.78 \%)\end{array}$ & $\begin{array}{l}219 \\
(95.78 \%)\end{array}$ & 0.998 & 0.012 & $\begin{array}{l}83.57 \\
(8.02)\end{array}$ & 105.11 & 99.17 & 18.15 \\
\hline 7 & Lindane & 15.85 & 181 & $\begin{array}{l}183 \\
(96.48 \%)\end{array}$ & $219(54.23 \%)$ & 0.999 & 0.011 & $\begin{array}{l}77.84 \\
(9.33)\end{array}$ & 106.58 & 107.27 & 14.14 \\
\hline 8 & Chlorothalonil & 16.47 & 266 & $\begin{array}{l}264 \\
(76.28 \%)\end{array}$ & $\begin{array}{l}268 \\
(50.23 \%)\end{array}$ & 0.983 & 0.099 & $\begin{array}{l}110.41 \\
(7.02)\end{array}$ & 100.01 & 100.38 & 14.64 \\
\hline 9 & $\delta-\mathrm{HCH}$ & 16.98 & 181 & $\begin{array}{l}183 \\
(92.49 \%)\end{array}$ & $219(57.85 \%)$ & 0.995 & 0.005 & $\begin{array}{l}105.04 \\
(5.2)\end{array}$ & 113.65 & 109.16 & 16.59 \\
\hline 10 & Dimethachlor & 17.83 & 134 & $\begin{array}{l}197 \\
(40.23 \%)\end{array}$ & $77(52.91 \%)$ & 0.993 & 0.056 & $\begin{array}{l}92.12 \\
(11.02)\end{array}$ & 102 & 98.45 & 1.93 \\
\hline 11 & Alachlor & 18.28 & 45 & $\begin{array}{l}160 \\
(42.28 \%)\end{array}$ & $\begin{array}{l}188 \\
(26.22 \%)\end{array}$ & 0.999 & 0.05 & $\begin{array}{l}92.57 \\
(8.91)\end{array}$ & 105.35 & 103.43 & 8.93 \\
\hline 12 & $\begin{array}{l}\text { Parathion- } \\
\text { methyl }\end{array}$ & 18.38 & 263 & $\begin{array}{l}109 \\
(42.21 \%)\end{array}$ & $\begin{array}{l}125 \\
(35.23 \%)\end{array}$ & 0.995 & 0.021 & $\begin{array}{l}85.92 \\
(7.19)\end{array}$ & 106.09 & 97.77 & 4.25 \\
\hline 13 & Heptachlor & 18.79 & 100 & $\begin{array}{l}272 \\
(42.28 \%)\end{array}$ & $\begin{array}{l}274 \\
(30.56 \%)\end{array}$ & 0.998 & 0.015 & $\begin{array}{l}111.7 \\
(8.26)\end{array}$ & 113.44 & 101.39 & 8.73 \\
\hline 14 & Malathion & 19.91 & 125 & $\begin{array}{l}127 \\
(65.59 \%)\end{array}$ & $93(47.54 \%)$ & 0.996 & 0.036 & $\begin{array}{l}86.17 \\
(6.6)\end{array}$ & 109.4 & 104.87 & 15.47 \\
\hline 15 & Chlorpyriphos & 20.23 & 97 & $\begin{array}{l}197 \\
(63.28 \%)\end{array}$ & $\begin{array}{l}199 \\
(41.56 \%)\end{array}$ & 0.997 & 0.022 & $\begin{array}{l}96.35 \\
(1.02)\end{array}$ & 109.84 & 105.52 & 13.55 \\
\hline 16 & Aldrin & 20.46 & 66 & $\begin{array}{l}263 \\
(57.63 \%)\end{array}$ & $91(22.73 \%)$ & 0.999 & 0.017 & $\begin{array}{l}93.45 \\
(5.81)\end{array}$ & 117.22 & 111.11 & 3.52 \\
\hline 17 & Pendimethylene & 21.87 & 252 & $\begin{array}{l}162 \\
(18.93 \%)\end{array}$ & $\begin{array}{l}181 \\
(20.43 \%)\end{array}$ & 0.998 & 0.056 & $\begin{array}{l}107.57 \\
(7.19)\end{array}$ & 102.92 & 99.3 & 13.06 \\
\hline 18 & Quinalphos & 22.77 & 146 & $118(65 \%)$ & $156(61 \%)$ & 0.999 & 0.031 & $\begin{array}{l}87.66 \\
(9.63)\end{array}$ & 109.33 & 101.39 & 10.75 \\
\hline 19 & Butachlor & 23.72 & 57 & $\begin{array}{l}176 \\
(68.89 \%)\end{array}$ & $\begin{array}{l}160 \\
(76.31 \%)\end{array}$ & 0.999 & 0.014 & $\begin{array}{l}112.24 \\
(10.25)\end{array}$ & 107.75 & 99.62 & 10.98 \\
\hline 20 & a- Endosulfan & 23.96 & 241 & $\begin{array}{l}195 \\
(80.25 \%)\end{array}$ & $\begin{array}{l}159 \\
(22.91 \%)\end{array}$ & 0.999 & 0.01 & $\begin{array}{l}113.99 \\
(7.29)\end{array}$ & 111.03 & 106.27 & 14.09 \\
\hline 21 & Profenophos & 24.28 & 337 & $97(68.11 \%)$ & $\begin{array}{l}139 \\
(66.97 \%)\end{array}$ & 0.998 & 0.016 & $\begin{array}{l}92.47 \\
(9.28)\end{array}$ & 98.43 & 94.16 & 4.04 \\
\hline 22 & $p, p-D D E$ & 25.85 & 246 & $\begin{array}{l}318 \\
(75.76 \%)\end{array}$ & $\begin{array}{l}248 \\
(54.81 \%)\end{array}$ & 0.962 & 0.023 & $\begin{array}{l}98.28 \\
(5.27)\end{array}$ & 102.56 & 96.05 & 14.58 \\
\hline
\end{tabular}




\begin{tabular}{|c|c|c|c|c|c|c|c|c|c|c|c|}
\hline \multirow{2}{*}{$\begin{array}{l}\text { Sl. } \\
\text { No. }\end{array}$} & \multirow[t]{2}{*}{ Pesticides } & \multirow[t]{2}{*}{$\mathrm{RT}^{\mathrm{a}}$} & \multicolumn{3}{|c|}{$\mathrm{m} / \mathrm{z}$ for confirmation with ion ratio } & \multirow[t]{2}{*}{${ }^{b} R^{2}$} & \multirow{2}{*}{$\begin{array}{l}\mathrm{LOQ}^{\mathrm{c}} \\
(\mathrm{ng} / \mathrm{ml})\end{array}$} & \multicolumn{3}{|c|}{ Recovery } & \multirow[t]{2}{*}{$\mathrm{RPD}^{\mathrm{e}}$} \\
\hline & & & $\begin{array}{l}\text { Target } \\
\text { lon }\end{array}$ & $\begin{array}{l}\mathrm{Q}_{1} \\
\left(\% \mathrm{Q}_{1} / \mathrm{T}\right)\end{array}$ & $\begin{array}{l}\mathrm{Q}_{2} \\
\left(\% \mathrm{Q}_{2} / \mathrm{T}\right)\end{array}$ & & & $\begin{array}{l}\mathrm{LOQ} \\
\left(\mathrm{SD}^{\mathrm{d}}\right)\end{array}$ & $\begin{array}{l}2 x \\
\text { LOQ }\end{array}$ & $5 \times L O Q$ & \\
\hline 23 & o,p-DDD & 25.85 & 235 & $165(76.43 \%)$ & $237(53.85 \%)$ & 0.993 & 0.018 & $\begin{array}{l}86.67 \\
(7.21)\end{array}$ & 102.47 & 98.51 & 4.33 \\
\hline 24 & Ethion & 27.52 & 231 & $97(60.28 \%)$ & $\begin{array}{l}153 \\
(50.78 \%)\end{array}$ & 0.997 & 0.017 & $\begin{array}{l}90.2 \\
(9.16)\end{array}$ & 102.7 & 98.72 & 12.62 \\
\hline 25 & p,p-DDD & 27.74 & 235 & $\begin{array}{l}165 \\
(56.28 \%)\end{array}$ & $\begin{array}{l}237 \\
(32.50 \%)\end{array}$ & 0.999 & 0.021 & $\begin{array}{l}91.94 \\
(12.09)\end{array}$ & 92.59 & 93.63 & 14.54 \\
\hline 26 & B-Endosulfan & 27.86 & 241 & $\begin{array}{l}195 \\
(65.23 \%)\end{array}$ & $\begin{array}{l}159 \\
(40.21 \%)\end{array}$ & 0.997 & 0.014 & $\begin{array}{l}89.809 \\
(14.20)\end{array}$ & 99.04 & 95.21 & 9.65 \\
\hline 27 & $\mathrm{p}, \mathrm{p}-\mathrm{DDT}$ & 27.87 & 235 & $165(52.28 \%)$ & $237(61.12 \%)$ & 0.996 & 0.015 & $\begin{array}{l}118.15 \\
(6.37)\end{array}$ & 110.78 & 101.28 & 1.85 \\
\hline 28 & $\begin{array}{l}\text { Endosulfan } \\
\text { sulphate }\end{array}$ & 29.7 & 272 & $274(53.37 \%)$ & $239(50.21 \%)$ & 0.998 & 0.017 & $\begin{array}{l}84.92 \\
(4.28)\end{array}$ & 100.26 & 96.56 & 14.94 \\
\hline 29 & Spiromesifen & 31.85 & 272 & $99(52.23 \%)$ & $273(36.16 \%)$ & 0.972 & 0.053 & $\begin{array}{l}80.38 \\
(2.98)\end{array}$ & 103.32 & 98.26 & 17.04 \\
\hline 30 & Bifenthrin & 32.97 & 181 & 166(53.27\%) & $165(62.74 \%)$ & 0.986 & 0.039 & $\begin{array}{l}97.25 \\
(7.23)\end{array}$ & 95.94 & 98.42 & 3.15 \\
\hline 31 & Fenpropathrin & 33.53 & 97 & $\begin{array}{l}181 \\
(96.97 \%)\end{array}$ & $\begin{array}{l}265 \\
(35.12 \%)\end{array}$ & 0.994 & 0.05 & $\begin{array}{l}83.49 \\
(8.29)\end{array}$ & 102.94 & 103.04 & 13.55 \\
\hline 32 & $\begin{array}{l}\text { Lamda- } \\
\text { cyhalothrin }\end{array}$ & 36.22 & 181 & 197(95.70\%) & 208(58.77\%) & 0.996 & 0.087 & $\begin{array}{l}82.47 \\
(7.08)\end{array}$ & 98.43 & 70.67 & 4.53 \\
\hline 33 & $\beta$-Cyfluthrin & 41.27 & 163 & $\begin{array}{l}206 \\
(65.23 \%)\end{array}$ & $\begin{array}{l}226 \\
(54.15 \%)\end{array}$ & 0.999 & 0.025 & $\begin{array}{l}82.4 \\
(4.09)\end{array}$ & 102.56 & 112.24 & 18.65 \\
\hline 34 & Cypermethrin & 42.22 & 181 & $\begin{array}{l}163 \\
(75.86 \%)\end{array}$ & $\begin{array}{l}127 \\
(47.59 \%)\end{array}$ & 0.968 & 0.035 & $\begin{array}{l}111.44 \\
(4.45)\end{array}$ & 102.47 & 113.99 & 7.53 \\
\hline 35 & Fenvalerate & 44.76 & 125 & $\begin{array}{l}167 \\
(57.88 \%)\end{array}$ & $\begin{array}{l}225 \\
(44.54 \%)\end{array}$ & 0.994 & 0.044 & $\begin{array}{l}97.75 \\
(5.23)\end{array}$ & 102.7 & 92.48 & 1.46 \\
\hline 36 & Deltamethrin & 47.82 & 181 & $\begin{array}{l}253 \\
(72.62 \%)\end{array}$ & $77(69.84 \%)$ & 0.996 & 0.041 & $\begin{array}{l}111.37 \\
(6.37)\end{array}$ & 85.36 & 98.29 & 13.43 \\
\hline
\end{tabular}

\section{Glassware and Equipments:}

Separating Funnel shaker (Yamato Scientific, Japan), vortex mixer (Spinix, Tarson, India), Rotary vacuum evaporator with temperature controlled water bath (HS 2001 NS, Germany), Turbo Vap evaporator (Caliper Life Sciences, Hopkinton, Massachusetts, USA) and 100$1000 \mu \mathrm{L}$ and $1-10 \mathrm{~mL}$ micropipettes (Eppendorf Research, Germany) were also used for sample preparation. The electronic analytical balance Sartorius GD603 (Sartorius, Germany) with readability $=0.001 \mathrm{ct} / 0.2 \mathrm{mg}$ was used for weighing. All the equipments were calibrated externally with certified agencies. All the glassware viz. conical flask (1000 mL), separating funnel (1000 mL), measuring cylinder $(500 \mathrm{ml}$ and $1000 \mathrm{ml})$ and volumetric flasks $(100 \mathrm{~mL})$, graduated tubes $(25 \mathrm{~mL})$ were calibrated and purchased from Borosil Glass Works Ltd., Gujarat, India. Membrane filter paper, Ultipor N66, Nylon 6,6 membrane, 13 mm (Pall Life Sciences, USA) and syringe filter (SGE Analytical Science, Australia) were used for filtration process.

\section{Preparation of stock and working standards:}

Stock solutions of each CRM were prepared into a $100 \mathrm{ml}$ volumetric flask with hexane:toluene (1:1) solvent mixture. Working standards of different concentration $\left(1,00,000 \mathrm{ngml}^{-1}, 10,000 \mathrm{ngml}^{-1}, 5,000 \mathrm{ngml}^{-1}, 2,500 \mathrm{ngml}^{-1}, 1,000 \mathrm{ngml}^{-1}, 500 \mathrm{ngml}^{-1}, 250 \mathrm{ngml}^{-1}, 100 \mathrm{ngml}^{-}\right.$ $1,50 \mathrm{ngml}^{-1}, 20 \mathrm{ngml}^{-1}$ and $10 \mathrm{ngml}^{-1}$ ) were prepared from the stock solution using dilution technique. All the stock and working solutions of 36 pesticide standards were stored under refrigerated condition $\left(-4^{\circ} \mathrm{C}\right)$, protected from sun light. 


\section{Sample preparation:}

The conventional liquid-liquid extraction (LLE) method was used for water samples using three different solvent mixtures namely $\mathrm{S}_{1}$ (EA:DCM 8:2), $S_{2}$ (Hexane:DCM 8:2) and $S_{3}(100 \%$ DCM) to check and compare the \% recovery (Fig. 3). Collected water samples were filtered through whatman glass fibre filter $(\mathrm{GF} / \mathrm{F}, 0.45 \mathrm{~mm})$ to remove suspended particles before extraction. Sample $(750 \mathrm{ml})$ was taken in separatory funnel (1 litre), $\mathrm{NaCl}(150 \mathrm{~g})$ was added to separatory funnel and mixed properly, extracted thrice with 70,40 and $40 \mathrm{~mL}$ of each solvent mixture $\left(S_{1}, S_{2}\right.$ and $\left.S_{3}\right)$ using separating funnel shaker @ $210 \mathrm{rpm}$ and allowed 15 min to settle down for clear solvent phase separation. Altogether $150 \mathrm{ml}(=70+40+40)$ of organic solvent layer was collected in a conical flask after passing over anhydrous $\mathrm{Na}_{2} \mathrm{SO}_{4}$. The collected solvent was evaporated to dryness in a rotary vacuum evaporator at $40^{\circ} \mathrm{C}$ and the volume was made up with $5 \mathrm{~mL}$ hexane. It was taken in tarbo-vap tube for evaporation to dryness using Turbo Vap LV. The volume was reconstituted in $1 \mathrm{~mL}$ acetone. After vortexing for $30 \mathrm{~s}$ and sonication for $5 \mathrm{~min}$., the acetone was transferred to $2 \mathrm{ml}$ vial for Gas Chromatography-Mass Spectrometric (GC-MS) analysis with proper filtration using syringe filter.

\section{Instrumental analysis:}

The final extracts were analyzed using GC-MS, QP 2010 Plus (Shimadzu Corp., Kyoto, Japan), with a mass selective detector (MSD).The oven conditions were: initial temperature of $40^{\circ} \mathrm{C}$ (hold for $1 \mathrm{~min}$ ), raised @ $25^{\circ} \mathrm{C} / \mathrm{min}$ to $130^{\circ} \mathrm{C}$, then @ $12^{\circ} \mathrm{C} / \mathrm{min}$ to $180^{\circ} \mathrm{C}$, and finally @ $3^{\circ} \mathrm{C} / \mathrm{min}$ to $280^{\circ} \mathrm{C}$, with a hold time of $7 \mathrm{~min}$. The injector temperature was $250^{\circ} \mathrm{C}$. Helium was used as a carrier gas with purity-99.999\%. The ion source temperature was $250^{\circ} \mathrm{C}$. The interface temperature was $280^{\circ} \mathrm{C}$. The instrument was operated in the spit mode with split ratio of 1:10. The injection volume was $2 \mu \mathrm{L}$. The MS conditions include solvent delay of $6 \mathrm{~min}$; scan rate of $0.50 / \mathrm{s}$ and scanned mass range of $50-500 \mathrm{~m} / \mathrm{z}$. All samples were analyzed in the Selected lon Monitoring (SIM) mode (Fig. 4).Data were acquired and processed by GC-MS Lab Solution Software (version 4.45). The compound specific retention times, $\mathrm{m} / \mathrm{z}$ ions and molecular mass for the identification, confirmation and quantification are represented in (Table 1). Pesticides were identified based on their retention times, quantification and identification transitions.

\section{Method validation:}

The method was validated following SANTE/11813/2017 guidelines with linearity, limit of detection (LOD), limit of quantification (LOQ), specificity, accuracy (\% recovery) and precision (\% RSD) (SANTE 2017). LOD was determined based on signal to noise ratio (S/N) 3:1 whereas $\mathrm{S} / \mathrm{N}$ ratio of 10:1 was used to determine the LOQ. The five-point $\left(10,20,50,100\right.$ and $\left.250 \mathrm{ng} \mathrm{ml}^{-1}\right)$ calibration curve of mixstandard solution was prepared for checking linearity with the regression coefficient $\left(R^{2}\right)$. A comparative recovery experiment in three replicates was carried out spiking blank water sample with the working mix-standard solution at fortification levels of LOQ, $2 \times L O Q$, and $5 \times L O Q$. The precision and trueness of the results, expressed as \%RPD was also calculated using $R P D=(M / N) * 100$ where $M=A+B$ and $N=$ $(A-B) / 2, A=$ Inter assay recovery and $B=$ Intra assay recovery (Tripathy et al. 2019).

\section{Risk assessment:}

Risk Quotient (RQ) was assessed and curtained following EPA's Level of Concern (LOC) for aquatic animals (e.g., fish and invertebrates), for presuming the potential risk associated with the presence of pesticide residues in the aquatic environment (USEPA 2017a). RQ was calculated as follows: $\mathrm{RQ}=\mathrm{EEC} / \mathrm{LC}_{50}$ or $\mathrm{EEC} / \mathrm{EC}_{50}$ or $\mathrm{EEC} / \mathrm{NOAEC}$ where, $\mathrm{EEC}=$ Estimated Environmental Concentration (i.e. detected pesticide level in environmental water); $\mathrm{LC}_{50}$ and $\mathrm{EC}_{50}=$ Median Lethal and Effective Concentration, respectively (for estimation of acute toxicity) and NOAEC = No Observed Adverse Effect Concentration (for estimation of chronic toxicity). Pesticide Properties Data Base (PPDB 2020) was used for the collection of all eco-toxicological ( $\mathrm{LC}_{50}$ or, $\mathrm{EC}_{50}$ or NOAEC) data (Table 2). 
Risk presumption in water ecosystem of river and pond.

\begin{tabular}{|c|c|c|c|c|c|c|c|c|c|c|}
\hline \multicolumn{11}{|l|}{ Aquatic animals } \\
\hline \multirow[t]{3}{*}{ Pesticides } & \multicolumn{5}{|c|}{ River Water } & \multicolumn{5}{|c|}{ Pond Water } \\
\hline & \multirow[t]{2}{*}{$\mathrm{EEC}^{\mathrm{a}}$} & \multirow[t]{2}{*}{$\mathrm{LC}_{50}$} & \multirow[t]{2}{*}{ NOAEC } & \multicolumn{2}{|l|}{$\mathrm{RQ}$} & \multirow[t]{2}{*}{ EEC } & \multirow[t]{2}{*}{$\mathrm{LC}_{50}$} & \multirow[t]{2}{*}{ NOAEC } & \multicolumn{2}{|l|}{$\mathrm{RQ}$} \\
\hline & & & & Acute & Chronic & & & & Acute & Chronic \\
\hline $\mathrm{T}-\mathrm{HCH}$ & 1.26 & 2.9 & 2900 & 0.43448 & 0.0004344 & 0.11 & 2.9 & 2900 & 0.0379 & 0.000037 \\
\hline T-DDT & 1.11 & 2510 & 130 & 0.0005 & 0.0085384 & 0.18 & 2510 & 130 & 0.000071 & 0.000062 \\
\hline T-Endosulfan & 0.59 & 2 & 0.0001 & 0.295 & 5900 & 0.03 & 2 & 0.0001 & 0.015 & 0.000017 \\
\hline Phorate & 0.005 & 13 & - & 0.000384 & - & 0.005 & 13 & - & 0.000385 & - \\
\hline Parathion-methyl & 0.031 & 2700 & - & 0.000011 & - & 0.031 & 2700 & - & 0.000011 & - \\
\hline Malathion & 0.015 & 18 & 91 & 0.00083 & 0.00016483 & - & - & - & - & - \\
\hline Chlorpyriphos & 0.075 & 25 & 0.14 & 0.00301 & 0.53571428 & 0.13 & 25 & 0.14 & 0.0052 & 0.928571 \\
\hline Quinalphos & 0.023 & 5 & - & 0.0046 & - & 0.083 & 0.005 & - & 16.6 & - \\
\hline Profenophos & 0.015 & 0.08 & 0.002 & 0.1875 & 7.5 & - & - & - & - & - \\
\hline Butachlor & 0.025 & 441 & - & 0.000056 & - & 0.047 & 441 & - & 0.000107 & - \\
\hline \multicolumn{11}{|c|}{ Semi-aquatic plants } \\
\hline & \multirow[t]{2}{*}{ EEC } & \multirow[t]{2}{*}{$\mathrm{EC}_{50}$} & \multirow[t]{2}{*}{ NOAEC } & \multicolumn{2}{|l|}{$\mathrm{RQ}$} & \multirow[t]{2}{*}{ EEC } & \multirow[t]{2}{*}{$\mathrm{EC}_{50}$} & \multirow[t]{2}{*}{ NOAEC } & \multicolumn{2}{|l|}{$\mathrm{RQ}$} \\
\hline & & & & Acute & Chronic & & & & Acute & Chronic \\
\hline $\mathrm{T}-\mathrm{HCH}$ & 1.26 & 2500 & 1900 & 0.000504 & 0.0006631 & 0.11 & 2500 & 1900 & 0.000044 & 0.000057 \\
\hline T-DDT & 1.11 & - & - & - & - & 0.18 & - & - & - & - \\
\hline T-Endosulfan & 0.59 & 2150 & - & 0.0002744 & - & 0.03 & 2150 & - & 0.0000139 & - \\
\hline Phorate & 0.005 & 1300 & - & 0.0000038 & - & 0.005 & 1300 & - & 0.0000038 & - \\
\hline Parathion-methyl & 0.031 & 1300 & - & 0.0000238 & - & 0.031 & 1300 & - & 0.0000238 & - \\
\hline Malathion & 0.015 & 13000 & - & 0.0000011 & - & - & 13000 & - & - & - \\
\hline Chlorpyriphos & 0.075 & 480 & 43 & 0.0001562 & 0.0017441 & 0.13 & 480 & 43 & 0.000271 & 0.003023 \\
\hline Quinalphos & 0.023 & - & - & - & - & 0.083 & - & - & - & - \\
\hline Profenophos & 0.015 & - & - & - & - & - & - & - & - & - \\
\hline Butachlor & 0.025 & 210 & - & 0.00011904 & - & 0.047 & 210 & - & 0.000224 & - \\
\hline
\end{tabular}

\section{Meteorological Parameters:}

Meteorological data (temperature, relative humidity and rain fall) were also collected from Department of Agricultural Meteorology and Physics, BCKV, Kalyani, for entire study period (Fig. 1). These data was used to correlate and discuss on the seasonal variation of occurrence of pesticide residues in environmental water samples.

Results And Discussion:

Method standardization: 
Different binary solvent mixtures and single solvent system were used for extraction of water samples. Extraction of pesticide residues having different polarities depends on the polarity of extraction solvent (Allen et al. 2015).To standardize the extraction solvent, three solvent mixture were considered for extraction namely $S_{1}$ (EA:DCM 8:2), $S_{2}$ (Hexane:DCM 8:2) and $S_{3}(100 \%$ DCM). Among these three solvent mixtures, highest \% recovery (77.85 to 110.5) was achieved in case of $S_{1}$ solvent mixture at fortification level of $0.10 \mathrm{ng} \mathrm{mL}^{-1}$. At the same fortification level other two solvent mixtures $\left(S_{2}\right.$ and $\left.S_{3}\right)$ could not extract all pesticides. Even these solvent mixtures showed average percent recovery from 11.52 to 258.03 (Fig. 3). Sibali et al. (2008) used hexane (100\%), DCM:Methanol (1:1), DCM:Hexane (1:1) and DCM $(100 \%)$ as extraction solvent mixtures. The researcher and his team found $100 \%$ DCM as the best extraction solvent giving recoveries above $70 \%$. Using the standardized extraction solvent mixture $\mathrm{S}_{1}$ (EA:DCM 8:2), the method was validated following SANCO/11813/2017guidelines. The LOQ of individual pesticide was determined and found within the range $0.011-0.087 \mathrm{ngmL}^{-1}$. A common LOQ of $0.1 \mathrm{ngmL}^{-1}$ was fixed for all 36 pesticides to study average percent recovery. The same is prescribed as standard value by EC (2016) and accordance with Govt. of India (Sankararamakrishnan et al. 2005; Raghuvanshi et al. 2014). Average percent recovery found at fortification levels of LOQ $\left(0.1 \mathrm{ngmL}^{-1}\right), 2 \times L O Q\left(0.2 \mathrm{ngmL}^{-1}\right)$ and $5 \times \mathrm{LOQ}\left(0.5 \mathrm{ngmL}^{-1}\right)$ were in the range 70.67-118.15. This data matched the criteria $(70-120)$ of SANTE guideline. \%RPD were calculated for individual pesticide and found satisfactory $(\leq 20 \%)$. The highest \% RPD was found in case of $\beta$-cyfluthrin (18.65) and the least was for fenvalerate (1.46) (Table 1).

\section{Monitoring of pesticide residues and effect of Seasonal variation:}

A total eighteen out of 36 pesticides were detected irrespective of seasons during the study. These 18 pesticides are organochlorine insecticides [a-HCH, $\beta-\mathrm{HCH}, \gamma-\mathrm{HCH}$ and $\delta-\mathrm{HCH}$ (total $\mathrm{HCH}$ ), endosulfan, $\mathrm{a}$-endosulfan and $\beta$-endosulfan (total endosulfan), $p^{\prime} p^{\prime}-\mathrm{DDE}, \mathrm{p}^{\prime} \mathrm{p}^{\prime}-$ DDT, o' $p^{\prime}-D D D$ and p'p'-DDD (total DDT)], organophosphate (OP) insecticides (phorate, parathion-methyl, malathion, chlorpyriphos, quinalphos and profenophos) and chloroacetanilide herbicide Butachlor. River water samples were found contaminated with all 18 pesticides except profenophos in summer. The water samples of pond were reported with residues of 16 pesticides except p'p'-DDD (winter), a-endosulfan (in summer) and $\beta$-endosulfan (in summer and winter seasons). Chlorpyriphos and butachlor residues were detected in tubewell water samples irrespective of seasons. No residues of other pesticides under study were detected in any of the environmental water samples irrespective of seasons.

Seven out of ninety six tube-well water samples were contaminated only with 2 pesticides (chlorpyriphos and butachlor) and others samples detected pesticide residues below limit of quantification (LOQ) of $0.1 \mathrm{ngmL}^{-1}$ for every season. The river water was contaminated with 18 pesticides including 11 organochlorines inspite of the restricted use (UNEP 2003) and low water affinity (Singh et al. 2012) of organochlorines (OCs).

The mean concentration of Total organochlorines $\left(T_{\text {OC }}\right)=$ Total $\mathrm{HCH}+$ Total DDT + Total endosulfan) detected in river water $\left(2.96 \mathrm{ng} \mathrm{mL}^{-1}\right)$ (Table. 2) despite the low water affinity (Singh et al. 2012) of OCs in water. These values were higher compared to those reported in other Indian rivers viz. Yamuna (Kaushik et al. 2008), Kuano (Singh and Mishra 2009) but lower than reported Toc level in Sembrong lake basin in Malaysia (Sharip et al. 2017). In this study, DDT isomers were detected more frequently in river water in contrary to other water sources. Although DDT is banned for use in agriculture, presence of its residues in river water may be indicated the use of DDT in National Malaria Eradication Programme (NMEP, Govt. of India) in India (NVBDCP 2016). Values of Total HCH (sum of HCH isomers) in the river system indicates non-point source of contamination. It is assumed as an old source of contamination due to isomer's least reactivity and the most persistent nature among $\mathrm{HCH}$ isomers (Wang et al. 2007).

Remarkably, OP pesticides were predominant in pond and tubewell water located in neighboring places within $1 \mathrm{~km}$ radius in contrary to the abundant presence of $\mathrm{OC}$ insecticide residues in river water system. A mean concentration of chlorpyriphos $\left(0.13 \mathrm{ngL}^{-1}\right) \mathrm{was}_{\text {found }}$ and the insecticide was frequently detected in pond water irrespective of season. In tube-well water, it was the second most found pesticide next to butachlor irrespective of season. The residues of OPs in pond water probably due to contamination from agricultural pesticides used nearby cultivated land (Reddy and Reddy 2010; Lari et al. 2014). The mean concentration of $T_{\text {OC }}$ was much lower in pond water ( 0.32 $\mathrm{ng} \mathrm{mL}^{-1}$ ) compared to river water throughout all seasons. Interestingly, residues of no synthetic pyrethroid (SP) insecticide were detected in any water throughout the study period. This is probably due to the photo instability of synthetic pyrethroids (Kocourek et al. 1987).

Seasonal residual data showed huge influence of environmental parameters (rain fall, temperature and relative humidity). Variation of environmental parameter in study period showed in Fig. 1. In monsoon season, mean rain fall $(50.9 \mathrm{~mm})$ was three times higher of summer and average residue found in different aquatic system also showed the highest. In tube-well water sample, insecticide chlorpyrifos $\left(0.157 \mathrm{ngmL}^{-1}\right)$ and the herbicide butachlor $\left(0.065 \mathrm{ng} \mathrm{mL}^{-1}\right)$ were detected in monsoon period predominantly. In river and pond water samples, pesticides was found in winter comparatively lower than summer, because average temperature of summer was expectedly higher than winter. Although winter season is major agricultural period of Bengal, this scenario also designates some non-point source of 
contaminations. Contamination by agricultural pesticides in neighboring pond water system may be endorsed to run-off during monsoon water from subsequent agricultural land (Reddy and Reddy 2010; Lari et al. 2014). Intensive agricultural practices performing in the neighborhood of water system was also the probable causes of recommended OP pesticides contamination in pond water (Agrawal et al. 2010) but banned OCs (PPQS 2020) residues leads to unknown sources of contamination. Seasonal variation of detected average residues of OP and OC pesticides in aquatic system (Fig. 5) showed different behavior (Fig. 6). Abundances of OC pesticides in river water higher than pond water while OPs were predominate in pond water. But both were getting rise in monsoon season. Nguyen and his coworkers, 2019 also reported maximum OC pesticide concentration in Dong Nai River at rainy season in their study. Rising of OCs' contamination in river water was related to run-off rain water to river but sources were not specific. Moreover, OCs has an affinity to gather in the river sediments due to their hydrophobic nature and high octanol-water partition coefficient (Yang et al. 2005; Masiá et al. 2013)

Most of the study areas consist of a well-drained sandy-loam soil and the ground water levels are 35-50 ft deep from surface. This ground water (Tube-well sample) showed seasonal contamination due to rapid transport of soil holding pesticides in monsoon (butachlor and chlorpyrifos) with low water solubility and high Log $\mathrm{K}_{\text {ow }}$ (octanal-water partition coefficient) (Yang et al. 2005; Masiá et al. 2013). Table 3 lists the physicochemical properties of the pesticides inspected. 
Table 3

Physicochemical properties of the target pesticides.

\begin{tabular}{|c|c|c|c|c|c|}
\hline Compound & $\begin{array}{l}\text { Molecular } \\
\text { formula }\end{array}$ & $\begin{array}{l}\text { Solubility in water } \\
\left(\mathrm{mg} \mathrm{L}^{-1}\right)\end{array}$ & $\begin{array}{l}\log D \\
(\mathrm{pH} 7.4)\end{array}$ & Vapor pressure (mPa) & Log Koc \\
\hline 4-Br-2-Cl- phenol & $\mathrm{C}_{6} \mathrm{H}_{4} \mathrm{BrClO}$ & - & - & 0.000308 & - \\
\hline Trifluralin & $\mathrm{C}_{13} \mathrm{H}_{16} \mathrm{~F}_{3} \mathrm{~N}_{3} \mathrm{O}_{4}$ & 0.221 & 4.6 & 9.5 & 3.940 \\
\hline Phorate & $\mathrm{C}_{7} \mathrm{H}_{17} \mathrm{O}_{2} \mathrm{PS}_{3}$ & 50 & 3.6 & 112 & 3.370 \\
\hline $\mathrm{a}-\mathrm{HCH}$ & $\mathrm{C}_{6} \mathrm{H}_{6} \mathrm{Cl}_{6}$ & 2 & 3.82 & 5.99 & 3.456 \\
\hline Atrazine & $\mathrm{C}_{8} \mathrm{H}_{14} \mathrm{ClN}_{5}$ & 35 & 2.2 & 0.039 & 2.000 \\
\hline$\beta-\mathrm{HCH}$ & $\mathrm{C}_{6} \mathrm{H}_{6} \mathrm{Cl}_{6}$ & 0.2 & 3.82 & 4.06 & 3.456 \\
\hline Lindane & $\mathrm{C}_{6} \mathrm{H}_{6} \mathrm{Cl}_{6}$ & 8.52 & 3.82 & 4.4 & 3.456 \\
\hline Chlorothalonil & $\mathrm{C}_{8} \mathrm{Cl}_{4} \mathrm{~N}_{2}$ & 0.81 & 3.12 & 0.076 & 3.075 \\
\hline$\delta-\mathrm{HCH}$ & $\mathrm{C}_{6} \mathrm{H}_{6} \mathrm{Cl}_{6}$ & 31.4 & 3.82 & - & 3.456 \\
\hline Dimethachlor & $\mathrm{C}_{13} \mathrm{H}_{18} \mathrm{ClNO}_{2}$ & 2300 & 2.63 & 0.64 & 2.806 \\
\hline Alachlor & $\mathrm{C}_{14} \mathrm{H}_{20} \mathrm{ClNO}_{2}$ & 240 & 2.99 & 2.9 & 3.002 \\
\hline Parathion-methyl & $\mathrm{C}_{8} \mathrm{H}_{10} \mathrm{NO}_{5} \mathrm{PS}$ & 55 & 2.94 & 0.2 & 2.977 \\
\hline Heptachlor & $\mathrm{C}_{10} \mathrm{H}_{5} \mathrm{Cl}_{7}$ & 0.056 & 5.54 & 53 & 4.389 \\
\hline Malathion & $\mathrm{C}_{10} \mathrm{H}_{19} \mathrm{O}_{6} \mathrm{PS}_{2}$ & 148 & 2.76 & 3.1 & 2.878 \\
\hline Chlorpyriphos & $\mathrm{C}_{9} \mathrm{H}_{11} \mathrm{Cl}_{3} \mathrm{NO}_{3} \mathrm{PS}$ & 1.05 & 4.78 & 1.43 & 3.979 \\
\hline Aldrin & $\mathrm{C}_{12} \mathrm{H}_{8} \mathrm{Cl}_{6}$ & 0.027 & 5.91 & 8.6 & 4.589 \\
\hline Pendimethylene & $\mathrm{C}_{13} \mathrm{H}_{19} \mathrm{~N}_{3} \mathrm{O}_{4}$ & 0.33 & 4.83 & 3.34 & 4.005 \\
\hline Quinalphos & $\mathrm{C}_{12} \mathrm{H}_{15} \mathrm{~N}_{2} \mathrm{O}_{3} \mathrm{PS}$ & 17.8 & 3.3 & 0.346 & 3.160 \\
\hline Butachlor & $\mathrm{C}_{17} \mathrm{H}_{26} \mathrm{ClNO}_{2}$ & 20 & 4.09 & 0.24 & 3.605 \\
\hline a- Endosulfan & $\mathrm{C}_{9} \mathrm{H}_{6} \mathrm{Cl}_{6} \mathrm{O}_{3} \mathrm{~S}$ & 0.32 & 2.6 & 8.3 & 4.060 \\
\hline Profenophos & $\mathrm{C}_{11} \mathrm{H}_{15} \mathrm{BrClO}_{3} \mathrm{PS}$ & 28 & 4.4 & 2.53 & 3.770 \\
\hline $\mathrm{p}, \mathrm{p}-\mathrm{DDE}$ & $\mathrm{C}_{14} \mathrm{H}_{8} \mathrm{Cl}_{4}$ & 0.0265 & 6.46 & - & 4.890 \\
\hline o,p-DDD & $\mathrm{C}_{14} \mathrm{H}_{10} \mathrm{Cl}_{4}$ & 0.06764 & 5.84 & 0.18 & 4.553 \\
\hline Ethion & $\mathrm{C}_{9} \mathrm{H}_{22} \mathrm{O}_{4} \mathrm{P}_{2} \mathrm{~S}_{4}$ & 2 & 4.94 & 0.2 & 4.063 \\
\hline$p, p-D D D$ & $\mathrm{C}_{14} \mathrm{H}_{10} \mathrm{Cl}_{4}$ & 0.09 & 5.84 & 0.18 & 4.553 \\
\hline$\beta$-Endosulfan & $\mathrm{C}_{9} \mathrm{H}_{6} \mathrm{C}_{16} \mathrm{O}_{3} \mathrm{~S}$ & 0.32 & 2.6 & 8.3 & 4.030 \\
\hline $\mathrm{p}, \mathrm{p}-\mathrm{DDT}$ & $\mathrm{C}_{14} \mathrm{H}_{9} \mathrm{Cl}_{5}$ & 0.025 & 6.22 & - & 4.760 \\
\hline Endosulfan sulphate & $\mathrm{C}_{9} \mathrm{H}_{6} \mathrm{Cl}_{6} \mathrm{O}_{3} \mathrm{~S}$ & 0.32 & 3.87 & 0.83 & 3.481 \\
\hline Spiromesifen & $\mathrm{C}_{23} \mathrm{H}_{30} \mathrm{O}_{4}$ & 0.13 & 5.25 & 0.007 & 4.233 \\
\hline Bifenthrin & $\mathrm{C}_{23} \mathrm{H}_{22} \mathrm{ClF}_{3} \mathrm{O}_{2}$ & 0.001 & 6.93 & 0.0178 & 5.146 \\
\hline
\end{tabular}




\begin{tabular}{|c|c|c|c|c|c|}
\hline Compound & $\begin{array}{l}\text { Molecular } \\
\text { formula }\end{array}$ & $\begin{array}{l}\text { Solubility in water } \\
\left(\mathrm{mg} \mathrm{L}^{-1}\right)\end{array}$ & $\begin{array}{l}\log D \\
(\mathrm{pH} 7.4)\end{array}$ & Vapor pressure $(\mathrm{mPa})$ & Log Koc \\
\hline Fenpropathrin & $\mathrm{C}_{22} \mathrm{H}_{23} \mathrm{NO}_{3}$ & 0.33 & 5.82 & 0.76 & 4.544 \\
\hline Lamda-cyhalothrin & $\mathrm{C}_{23} \mathrm{H}_{19} \mathrm{ClF}_{3} \mathrm{NO}_{3}$ & 0.005 & 6.32 & 0.0002 & 4.815 \\
\hline$\beta$-cyfluthrin & $\mathrm{C}_{22} \mathrm{H}_{18} \mathrm{Cl}_{2} \mathrm{FNO}_{3}$ & 0.0019 & 6.13 & 0.000028 & 4.712 \\
\hline Cypermethrin & $\mathrm{C}_{22} \mathrm{H}_{19} \mathrm{Cl}_{2} \mathrm{NO}_{3}$ & 0.01 & 6.05 & 0.00023 & 4.670 \\
\hline Fenvalerate & $\mathrm{C}_{25} \mathrm{H}_{22} \mathrm{ClNO}_{3}$ & 0.001 & 6.28 & 0.0192 & 4.791 \\
\hline Deltamethrin & $\mathrm{C}_{22} \mathrm{H}_{19} \mathrm{Br}_{2} \mathrm{NO}_{3}$ & 0.0002 & 6.12 & 0.0000124 & 4.705 \\
\hline
\end{tabular}

Although, in summer there is some reduction of water volume in river and pond for rising of temperature, (Sharip et al. 2017; Kaushik et al. 2012) total-pesticide concentration was much higher in monsoon than summer and winter period (Fig. 5). Tanabe et al. (2001) reported maximum residue in Shinano River in the month of May when most applications were conducted.

\section{Risk assessment:}

Aquatic as well as humans ecosystem is very much scarring due to the biotransformation (Le Du-Lacoste et al. 2013) and bioaccumulation (Luna-Acosta et al. 2015) of pesticide residues in aqueous system.

In India, due to persistence nature in the environment of DDT (since 1993) and $\mathrm{HCH}$ (since 1997) restriction was imposed in their agricultural (UNEP 2003; PPQS 2020) as well as human health use (UNEP 2003; NVBDCP 2016). Remarkable presence of these nonagricultural pesticides in water moiety is very alarming in spite of their restrictions. These pesticides were also key suppliers of global persistent organic pesticide (POP) circulation (Yadav et al. 2015). Mankind directly depends on these water and aquatic life, so the risk connected with the contaminated water system was evaluated in terms of humans (EC 2016) and aquatic health (USEPA 2017a).

EC limit for single pesticide in drinking water is $0.10 \mathrm{ngmL}^{-1}$ (EU 1998). Interestingly more than $50 \%$ monsoon samples has exceeded the threshold for both pond and river water. Conversely tube-well water was safe for drinking as it was below the total pesticides limits irrespective of season.

To evaluate the possible ecological risk (acute and chronic) associated with the pesticides contaminated river and pond water risk quotient (RQ) was used (Table.2). The RQ level of concern (LOC) of semi-aquatic (e.g., marimo and algae) plants was 1 , so the RQ values $(<1)$ showed no possible risk on the aquatic ecosystems. But in case of $\mathrm{T}-\mathrm{HCH}(\mathrm{RQ}=0.434)$ in river aquatic animals (e.g., fish; Oncorhynchusmykiss), estimated RQ value was very closer to the limiting marks of EPA's LOC for acute toxicity in terms of Acute High Risk (0.500). Chen et al. 2020 also indicated OC pesticides as a moderate risk group in their study at Shanghai river, China. Significantly RQ of total endosulfan (0.295) crossed acute toxicity in river fish in terms of Acute Endangered Species $(L O C=0.050)$ and showed very high risk in chronic toxicity $R Q=5900$ compared to $L O C=1$. Kapsi et al. (2018) and his team also reported a-endosulfan as medium risk in their study at Louros river, Greece. Profenofos also indicated chronic toxicity threat in river water unlike others OPs. However, in pond water system there was no ecological hazard $(\mathrm{RQ}<1)$ for total-HCHs, total-DDTs and total-Endosulfan. In this study showed, the borderline RQ value of chlorpyrifos (0.928) comparing the LOC for Chronic Risk (1.0) in pond water fish, indicating future risk. Ccanccapa et. al. (2016) also reported that chlorpyrifos is the most frequent occurring pesticide in Ebro river water. Subsequently, the outcomes of this study are originated very serious for aquatic habitat around the study area.

\section{Conclusion}

In this study, an effective and profound method involving liquid-liquid extraction (LLE) and GCMS detection was standardized for determination of selected 36 pesticides in surface and ground water. EA and DCM (8:2, v/v) solvent system for LLE showed to be the best compared to other solvent systems. Method was validated according to EC guidelines and applied for observing of 36 pesticide residues (OCs, OPs and others) in different aquatic systems with seasonal variations. Different residues distribution of OPs and OCs was evaluated in river and pond water system with changes of environmental conditions. Comparatively higher concentration of pesticide residues 
occurred during monsoon period compared to summer and winter. Despite the restricted use of persistent OCs, river water samples were found to be contaminated with high $\mathrm{OC}$ residues which reflect non-point sources of contaminations.

In most of the samples, the pesticide residue levels spotted were higher than EC recommended drinking water quality standards. Risk assessment in the aquatic system was assessed where the potential risk on aquatic bionetwork in terms of acute and chronic toxicity was also observed for $\mathrm{OC}$ pesticides in river aquatic ecosystem. Therefore, this study initiates reference line data for possible execution of pollution control and governing decision-making policies in Barrackpore and Kalynai, West Bengal.

\section{Declarations}

\section{Acknowledgements}

The instrumental and infrastructural facilities extended by the AINP on Pesticides Residue Laboratory, Directorate of research, Bidhan Chandra Krishi Viswavidyalaya (BCKV), West Bengal, India, are duly acknowledged.

Funding: The authors are thankful to Indian Council of Agricultural Research (ICAR), New Delhi, India, for financial assistance.

Author contribution: SB: critical review, methodology, software and drafting of the manuscript; RP: ideation and drafting; SM: critical review; MBS: critical review and expert view; DKH: critical review and expert view; SS: literature review and expert view; RK:

conceptualization, ideation, critical review, supervision and expert view and. All authors contributed to the research article and approved the final version.

Data availability: Provided in manuscript

\section{Compliance with ethical standards}

Ethical approval: Not applicable.

Consent to participate: The authors have consent to participate.

Consent to publish: The authors have consent to publish.

Competing interests: The authors declare that they have no conflict of interest.

\section{References}

1. Allen G, Halsall CJ, Ukpebor J, Paul ND, Ridall G, Wargent JJ (2015) Increased occurrence of pesticide residues on crops grown in protected environments compared to crops grown in open field conditions. Chemosphere 119:1428-1435.

2. Agrawal A, Pandey RS, Sharma B (2010) Water pollution with special reference to pesticide contamination in India. Journal of Water Resource and Protection 2:432-448.

3. Arias-Estévez M, López-Periago E, Martínez-Carballo E, Simal-Gándara J, Mejuto JC, García-Río L (2008) The mobility and degradation of pesticides in soils and the pollution of groundwater resources. AgricEcosyst Environ 123(4): 247-260.

4. Awofolu RO, Fatoki OS (2003) Persistent organochlorines pesticides residues in freshwater systems and sediments from the Eastern Cape, South Africa. Water SA 29(3):323-330.

5. Calhoun Y (2005) Water pollution. New York: Chelsea House Publisher, USA, pp 1-7.

6. Ccanccapa A, Masiá A, Navarro-Ortega A, Picó Y, Barceló D (2016) Pesticides in the Ebro River basin: Occurrence and risk assessment, Environmental Pollution 211:414-424. https://doi.org/10.1016/j.envpol.2015.12.059.

7. Chen C, Zou W, Chen S, Zhang K, Ma L (2020) Ecological and health risk assessment of organochlorine pesticides in an urbanized river network of Shanghai, China. Environ SciEur 32:42. https://doi.org/10.1186/s12302-020-00322-9.

8. Duttweiler DW, Malakhov SG (1977) U.S.A. - U.S.S.R. on environmental transport and transformation of pesticides. J Agric Food Chem 25(5): 975-978.

9. EC (European Commission) (2016) A Report from the Commission on synthesis Report on the Quality of Drinking Water in the Union Examining Member States' Reports for the 2011-2013 Period, Foreseen under Article 13(5) of Directive 98/83/ec. Brussels, 20.10.2016 COM (2016) 666 final. http://ec.europa.eu/environment/water/water-drink/pdf/reports/EN.pdf. Accessed 28 February 2020. 
10. Erkmen B, Yerli S, Erkakan F, Kolankaya D (2013) Persistent organchlorine pesticide residues in water and sediment sample from Lake Manyas, Turkey. J Environ Biol 34:171-176.

11. EU (1998) European union drinking water standards. https://www.lenntech.com/applications/drinking/standards/eu-s-drinking-waterstandards.htm. Accessed 01 July 2020.

12. Hassaan MA, El Nemr A (2020) Pesticides pollution: Classifications, human health impact, extraction and treatment techniques. The Egyptian Journal of Aquatic Research 46(3):207-220

13. Hatrík Š, Tekel' J (1996) Extraction methodology and chromatography for the determination of residual pesticides in water. J Chromatogr A 733(1-2):217-233. https://doi:10.1016/0021-9673(95)00725-3.

14. Hegde NG (2012) Water scarcity and security in India. BAIF at the Indian Science Congress 2012. https://www.indiawaterportal.org/articles/water-scarcity-and-security-india. Accessed 25 October 2020.

15. Kapsi M, Tsoutsi C, Paschalidou A, Albanis T (2018) Environmental monitoring and risk assessment of pesticide residues in surface waters of the Louros River (N.W. Greece). Sci. Total Environ. Sci Total Environ 650:21882190. https://doi:10.1016/j.scitotenv.2018.09.185.

16. Karaouzas I, Theodoropoulos C, Vardakas L, Kalogianni E, Skoulikidis NT (2018) A review of the effects of pollution and water scarcity on the stream biota of an intermittent Mediterranean basin. River Research and Applications 34(4):291-299. https://doi:10.1002/rra.3254.

17. Kaushik CP, Sharma HR, Jain S, Dawra J, Kaushik A (2008) Pesticide residues in river Yamuna and its canals in Haryana and Delhi, India. Environ Monit Assess 144:329-340. https://doi.org/10.1007/s10661-007-9996-4.

18. Kaushik CP, Sharma HR, Kaushik A (2012) Organochlorine pesticide residues in drinking water in the rural areas of Haryana, India. Environ Monit Assess 184:103-112. https://doi.org/10.1007/s10661-011-1950-9.

19. KMDA (2020) Water \& Sanitation Sector. Kolkata Metropolitan Development Authority. Available at: www.kmdaonline.org/home/ws_sector_info. Accessed 20 February 2020.

20. Kocourek V, Havlíková L,Zemanová I (1987) Photostability of synthetic pyrethroids on treated grain. Z LebensmUntersForch 185:1416. https://doi.org/10.1007/BF01083333.

21. Kouzayha A, Rabaa AR, Iskandarani MA, Beh D, Budzinski H, Jaber F (2012) Multiresidue method for determination of 67 pesticides in water samples using solid-phase extraction with centrifugation and gas chromatography-mass spectrometry. American Journal of Analytical Chemistry 3:257-265. https://doi.org/10.4236/ajac.2012.33034.

22. Lari SZ, KhanNA, Gandhi KN, Meshram TS, Thacker NP (2014) Comparison of pesticide residues in surface water and ground water of agriculture intensive areas. J Environ Health Sci Eng 12:11.

23. Le Du-Lacoste M, Akcha F, Devier MH, Morin B, Burgeot T, Budzinski H (2013) Comparative study of different exposure routes on the biotransformation and genotoxicity of PAHs in the flatfish species, Scophthalmusmaximus.Environ SciPollut Res 20(2):690-707. https://doi.org/10.1007/s11356-012-1388-9.

24. Luna-Acosta A, Budzinski H, Le Menach K, Thomas-Guyon H, Bustamante $P(2015)$ Persistent organic pollutants in a marine bivalve on the Marennes-Oleron Bay and the Gironde Estuary (French Atlantic coast)-Part 1: Bioaccumulation. Sci Total Environ 514:500-510. https://doi.org/10.1016/j.scitotenv.2014.08.071.

25. Leonard RA, Knisel WG (1988) Evaluating groundwater contamination potential from herbicide use. Weed Technology 2:201-216.

26. Mondal R, Mukherjee A, Biswas S, Kole RK (2018) GC-MS/MS determination and ecological risk assessment of pesticides in aquatic system: A case study in Hooghly River basin in West Bengal, India. Chemosphere 206:217-230.

27. Masiá A, Campo J, Vázquez-Roig P, Blasco C, Picó Y (2013) Screening of currently used pesticides in water, sediments and biota of the Guadalquivir River Basin (Spain). J Hazard Mater 263(1):95-104. https://doi:10.1016/j.jhazmat.2013.09.035.

28. Matirkatha (2021) Comprehensive district agriculture plan for nadia district. C-DAP report http://matirkatha.net/wpcontent/uploads/2016/01/Nadia-District-Profile. Accessed 24 January 2021.

29. Maurya AK, Kumar A (2013) Organochlorine pesticides in the surface waters from Sharda River Region, Uttar Pradesh-India. The SIJ Transactions on Advances in Space Research \& Earth Exploration (ASREE) 1:1-7.

30. Nguyen TX, Nguyen BT, Tran HT T, Mai H, Duong TT, Bach QV (2019) Seasonal, Spatial Variation, and Potential Sources of Organochlorine Pesticides in Water and Sediment in the Lower Reaches of the Dong Nai River System in Vietnam. Arch Environ ContamToxicol 77(4):514-526. https://doi:10.1007/s00244-019-00653-6.

31. NVBDCP (2016) Operational Manual for Malaria Elimination in India 2016. (National Vector Borne Disease Control Programme) Directorate General of Health Services, Ministry of Health \& Family Welfare, Government of India. Version 1.

Page 13/19 
https://nvbdcp.gov.in/WriteReadData/l892s/5232542721532941542.pdf. Accessed 24 January 2021.

32. Ongley ED (1996) Control of Water Pollution from Agriculture. Food and Agriculture Organization of the United Nations, USA.

33. PPDB (Pesticide Properties Data Base) (2021) Agriculture \& Environment Research Unit (AERU). University of Hertfordshire. https://sitem.herts.ac.uk/aeru/ppdb/en/index.htm. Accessed 20 January 2021.

34. PPQS (2021) Banned pesticides list. Ministry of agriculture \& farmers welfare. Department of agriculture, cooperation \& farmers welfare. Government of India. https://ppqs.gov.in/industrycorner/banned-pesticides. Accessed 20 January 2021.

35. Raghuvanshi D, Pandey R, Pandey V, Sharma PK, Shukla DN (2014) Physicochemical and pesticide analysis of river Ganga in Allahabad city, Uttar Pradesh, India. Asian Journal of Biochemical and Pharmaceutical Research 3:239-244.

36. Reddy KN, Reddy H (2010) Pesticide residues in surface water of lakes around hyderabad, India. Pesticide Research Journal 22(2):111-115.

37. Rickert D, Schlüter M, Wallmann K (2002) Dissolution kinetics of biogenic silica from the water column to the sediments. Geochimica et Cosmochimica Acta 66:439-455. https://doi.org/10.1016/S0016-7037(01)00757-8.

38. Sangchan W, Hugenschmidt C, Ingwersen J, Schwadorf K, Thavornyutikarn P,Pansombat K, Streck T (2012) Short-term dynamics of pesticide concentrations and loads in a river of an agricultural watershed in the outer tropics. AgricEcosyst Environ 158:1-14. https://doi.org/10.1016/j.agee.2012.05.018.

39. Sankararamakrishnan N, Sharma AK, Sanghi R (2005) Organochlorine and organophosphorous pesticide residues in ground water and surface waters of Kanpur, Uttar Pradesh, India. Environ Int 31:113-120.

40. SANTE (Directorate-General for Health and Food Safety) (2017) Guidance document on analytical quality control and validation procedures for pesticide residues analysis in food and feed. European Commission. Document no. SANCO/11813/2017. http://www.eurl-pesticides.eu/userfiles/file/SANTE_11813_2017_MainChanges.pdf. Accessed 25 November 2017.

41. Schulz R (2004) Field studies on exposure, effects, and risk mitigation of aquatic nonpoint source insecticide pollution: a review. J Environ Qual 33:419-448.

42. Sharip Z, Hashim N, Suratman S (2017) Occurrence of organochlorine pesticides in a tropical lake basin. Environ Monit Assess 189:113.

43. Sibali LL, Okwonkwo JO, McCrindle RI (2008) Determination of selected organochlorine pesticide (OCP) compounds from the Jukskei River catchment area in Gauteng, South Africa. Water Sa 34:611-621.

44. Singh S, Mishra RN (2009) Occurrence of organochlorine pesticides residue in Kuano river of eastern Uttar Pradesh. J Environ Biol 30: 467-468.

45. Singh L, Choudhary SK, Singh PK (2012) Pesticide concentration in water and sediment of River Ganga at selected sites in middle Ganga plain. Int J Environ Sci 3(1):260-274

46. Skoulikidis TK, Vardakas L, Karaouzas I, Economou AN, Dimitriou E, Zogaris.S (2011) Assessing water stress in Mediterranean lotic systems: insights from an artificially intermittent river in Greece. Aquatic Sciences 73:581.

47. Székács A, Mörtl M, Darvas B (2015) Monitoring pesticide residues in surface and ground water in Hungary: surveys in $1990-2015$. Journal of Chemistry. https://doi:10.1155/2015/717948.

48. Tan GH (1992) Comparison of solvent extraction and solid-phase extraction for the determination of organochlorine pesticide residues in water. Analyst 117(7):1129-1132.

49. Tanabe A, Mitobe H, Kawata K, Yasuhara A, Shibamoto T (2001) Seasonal and Spatial Studies on Pesticide Residues in Surface Waters of the Shinano River in Japan. J Agric Food Chem 49(8):3847-3852. https://doi:10.1021/jf010025x.

50. Toccalino PL, Gilliom RJ, Lindsey BD, Rupert MG (2014) Pesticides in Groundwater of the United States: Decadal-Scale Changes, 1993-2011. Groundwater 52(S1):112-125. https://doi:10.1111/gwat.12176.

51. Tripathy V, Sharma KK, Yadav R, Devi S, Tayade A, Sharma K, Pandey P, Singh G, Patel AN, Gautam R, Gupta R, Kalra S, Shukla P, Walia S, Shakil NA (2019) Development, validation of QuEChERS-based method for simultaneous determination of multiclass pesticide residue in milk, and evaluation of the matrix effect. J Environ Sci Health B 1:13. https://doi:10.1080/03601234.2019.1574169.

52. Tsochatzis ED, Tzimou-Tsitouridou R, Menkissoglu-Spiroudi U, Karpouzas DG, Papageorgiou M (2012) Development and validation of an HPLC-DAD method for the simultaneous determination of most common rice pesticides in paddy water systems. Int $\mathrm{J}$ Environ Anal Chem 92:548-560. https://doi.org/10.1080/03067310903229943.

53. UNEP (United Nations Environment Programme) (2003) Global Reports on Regionally Based Assessment of Persistent Toxic Substances. United Nations Environment Programme. UNEP Chemicals, Geneva, Switzerland. https://wedocs.unep.org/handle/20.500.11822/675?show=full. 
54. USEPA (2020) Ecological Risk Assessment for Pesticides: Technical overview. United States Environmental Protection Agency https://www.epa.gov/pesticide-science-and-assessing-pesticide-risks/ecological-risk-assessment-pesticides-technical. Accessed 21 December 2020.

55. Wang YL, Yajuan S, John PG, Wei L (2007) Organochlorine pesticides in soils around guanting reservoir, China tieyu. Environ Geochem Health 29:491-501. https://doi.org/10.1007/s10653-007-9118-9.

56. Waite DT, Cessna AJ, Grover R, Kerr LA, Snihura AD (2002) Environmental concentrations of agricultural herbicides 2, 4-D and Triallate . J Environ Qual 31:129-144.

57. Yadav IC, Devi NL, Syed JH, Cheng Z, Li J, Zhang G, Jones KC (2015) Current status of persistent organic pesticides residues in air, water, and soil, and their possible effect on neighboring countries: a comprehensive review of India. Sci Total Environ 511:123-137.

58. Yang R, Jiang G, Zhou Q, Yuan C, Shi J (2005) Occurrence and distribution of organochlorine pesticides (HCH and DDT) in sediments collected from East China Sea. Environment International 31(6):799-804.

\section{Figures}

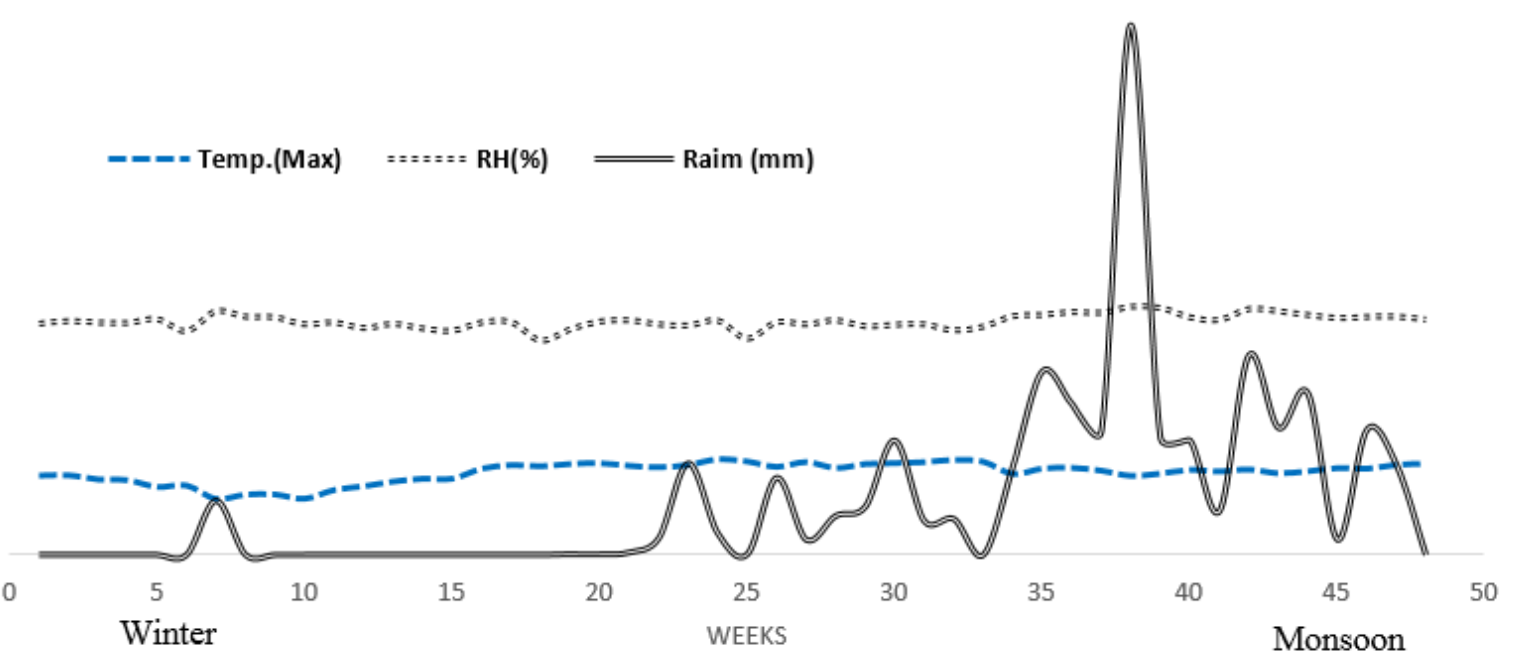

\section{Figure 1}

Agro-meteorological data [Temperature, Relative humidity $(\mathrm{RH})$ and rainfall] during the entire study period (48 weeks) 


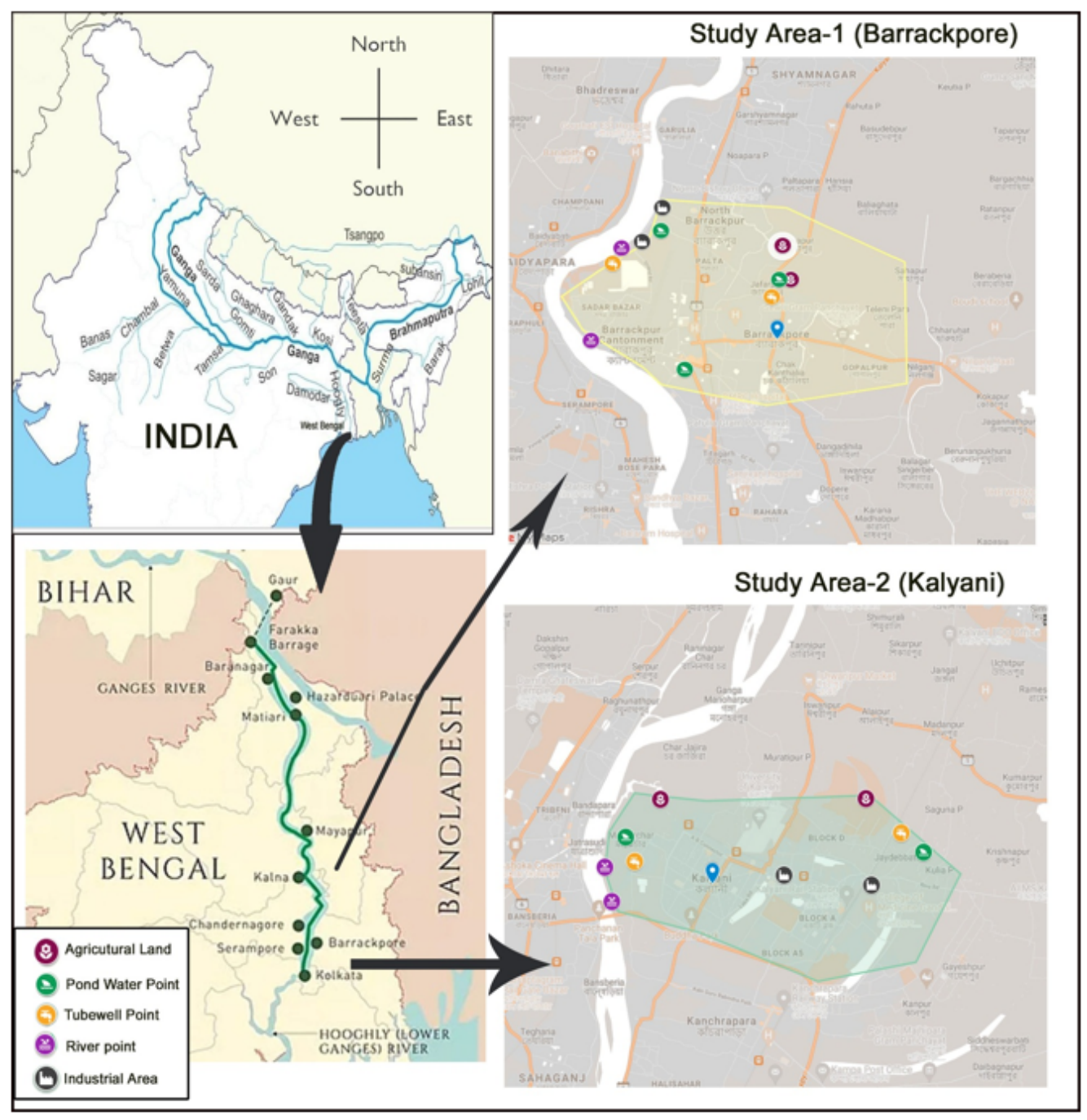

Figure 2

Study area (Sampling sites of the experiment)

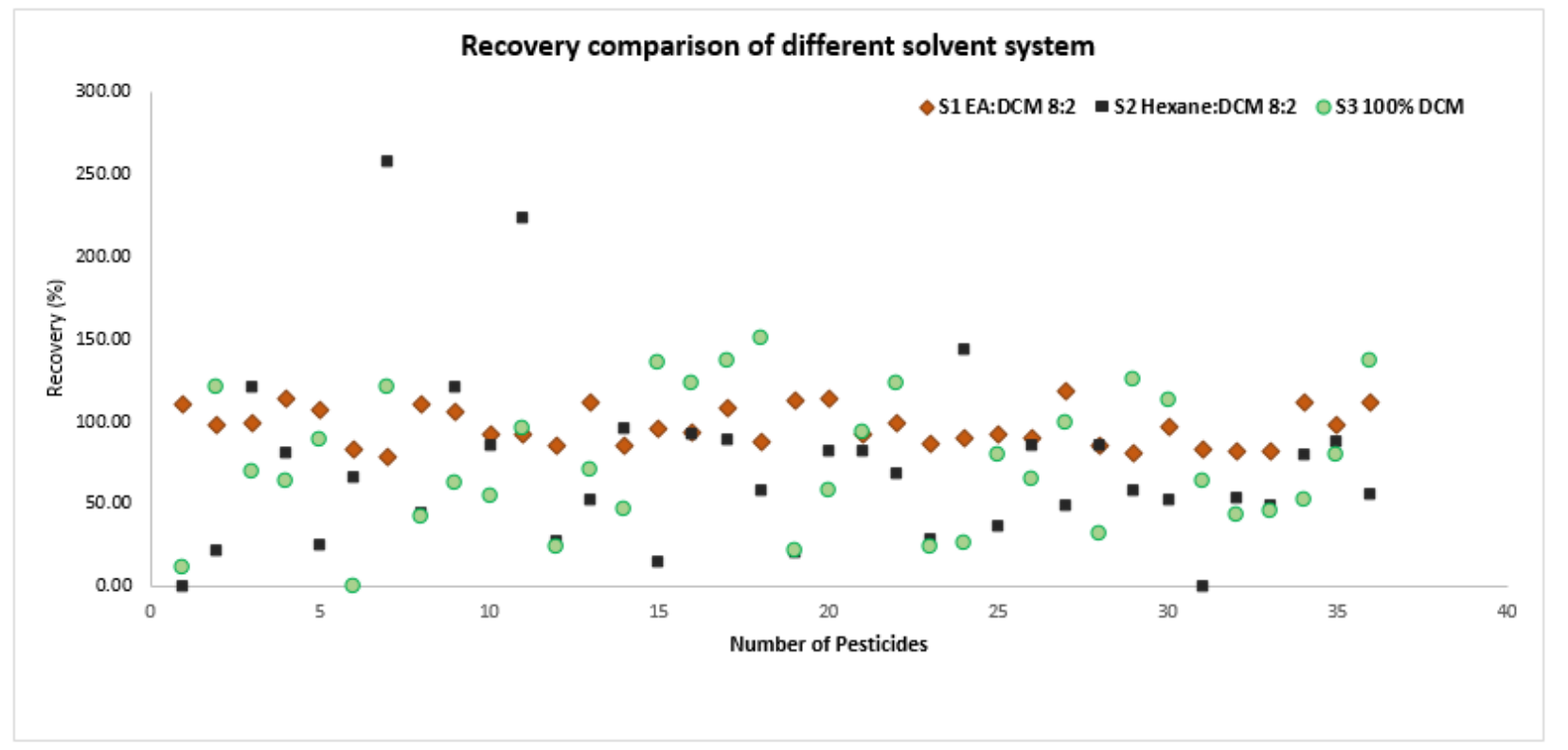

Figure 3 
Comparison of average percent recovery using different extraction solvent system S1 (EA:DCM 8:2), S2 (Hexane:DCM 8:2) and S3 (100\% DCM)

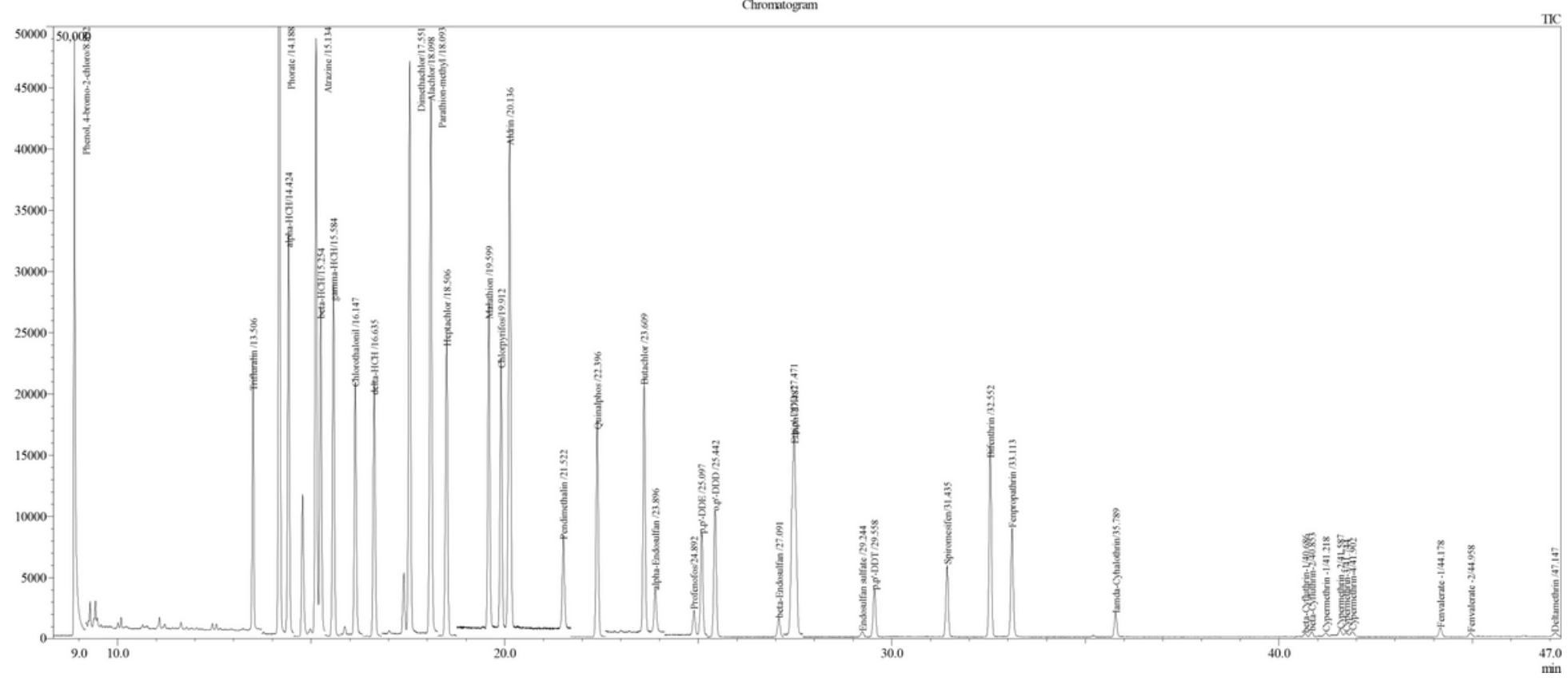

Figure 4

GC-MS Chromatogram of thirty six selected pesticide standards 


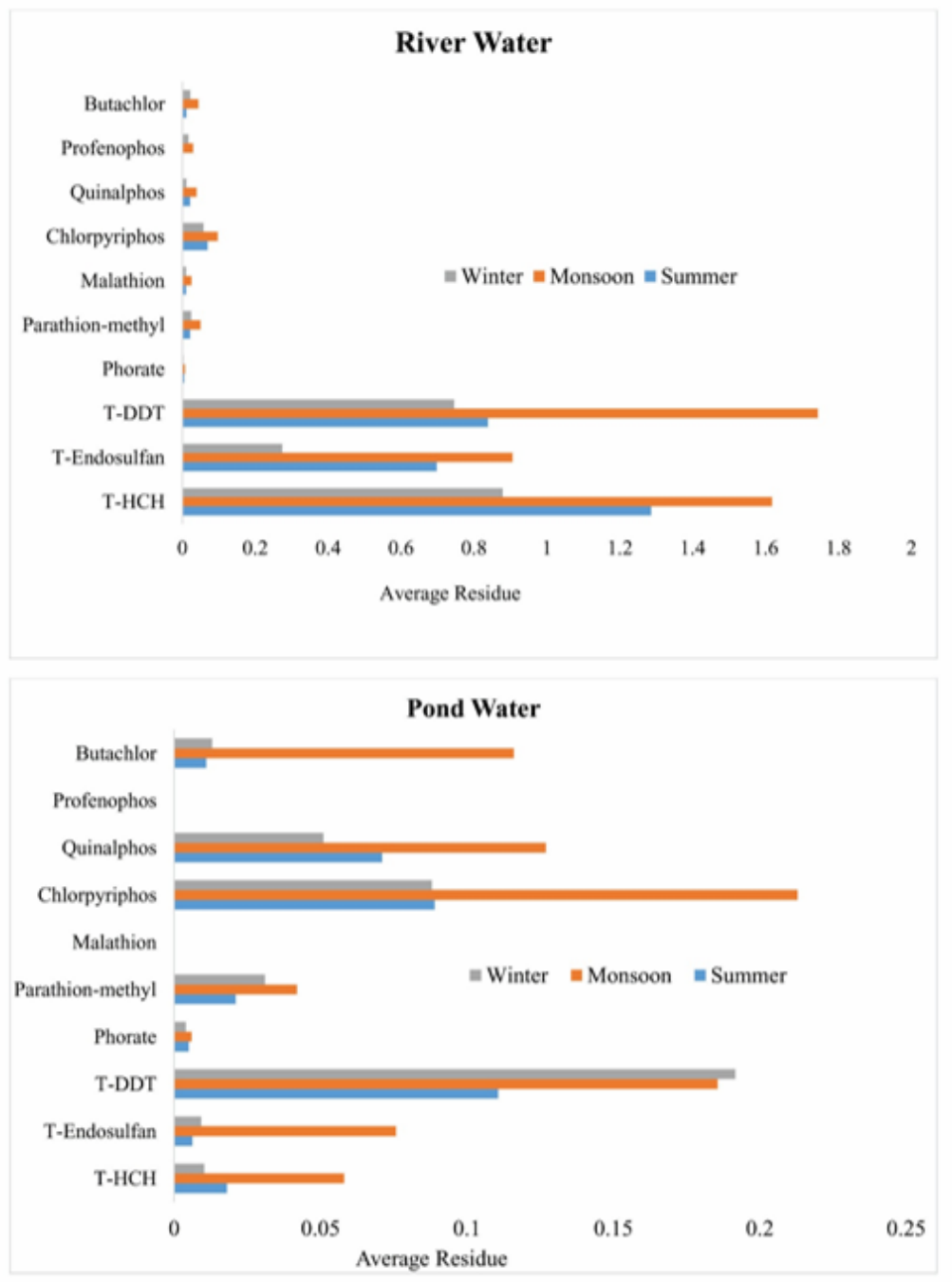

\section{Figure 5}

Seasonal average concentration of pesticide residues in pond and river water ( $\mathrm{ng} \mathrm{ml}-1)$ 


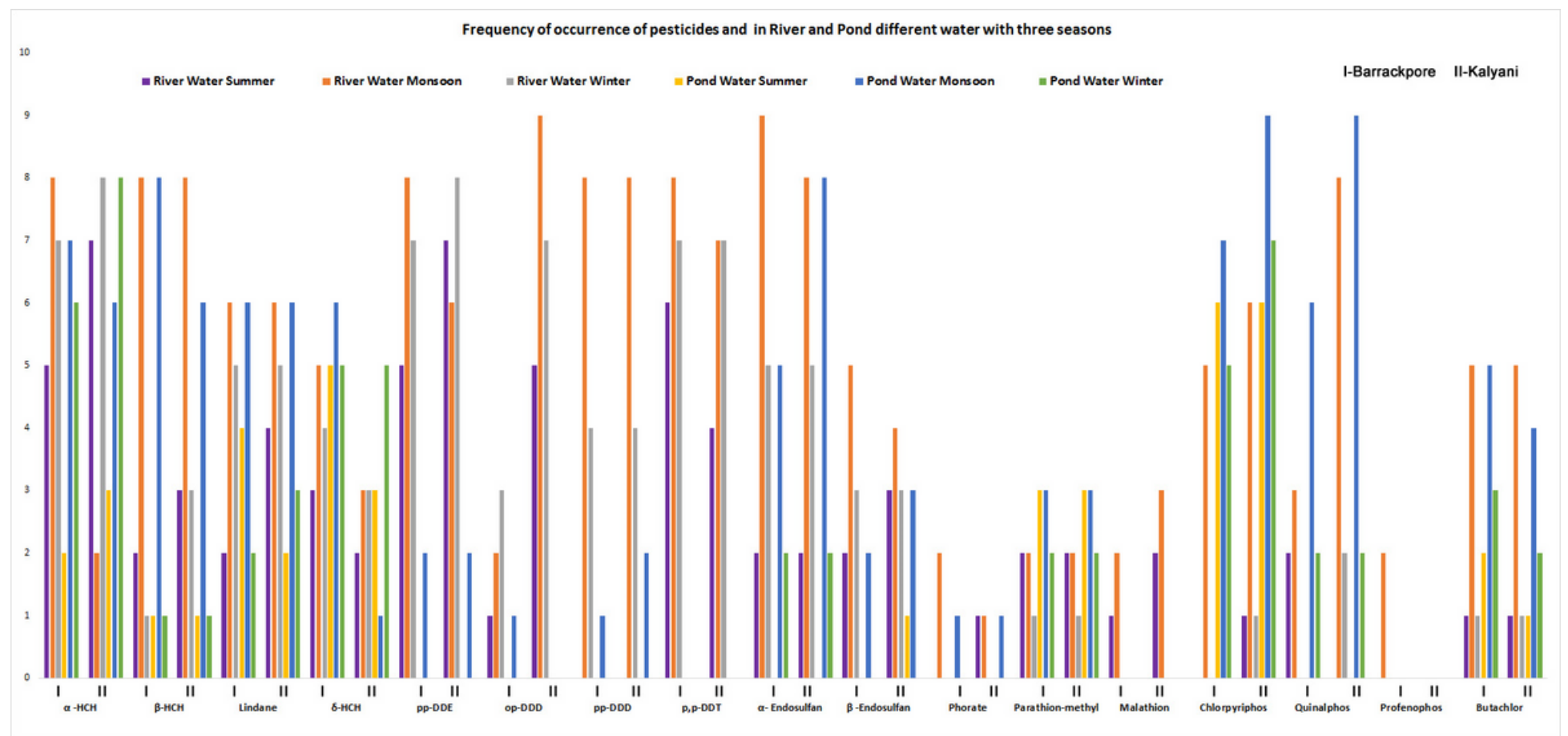

\section{Figure 6}

Frequency of occurrence of pesticides in River and Pond water with three seasons 